\title{
MULTIDRUG RESISTANCE AND INTEGRONS IN ESCHERICHIA COLI ISOLATED FROM CHICKEN IN GREECE
}

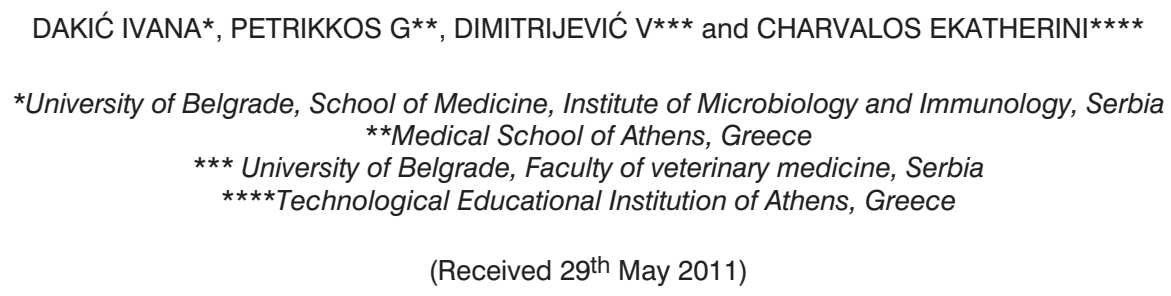

Enteric faecal flora of food-producing animals such as poultry is a potential reservoir for antimicrobial resistance genes which can be transferred to human pathogens via the food chain. The present study investigated 47 strains of Enterobacteriaceae recovered from a variety of chicken specimens for their resistance to 18 antimicrobial agents and the presence of integrons, and analyzed the association between integrons and antimicrobial susceptibility. Multidrug resistance was found in $82.9 \%$ of the isolates. The presence of integrons was shown in $68.1 \%$ of the strains tested: $42.5 \%$ carried a class 1 integron, $10.6 \%$ carried a class 2 integron, and 14.9\% had both class 1 and 2 integrons. An unusual cassette aacA4-catB3-dfrA1 was revealed in two class 1 integron-positive isolates. The association between the presence of an integron and multidrug resistance was significant $(p<0.05)$. The mercury resistance gene, merA, was found in $44.4 \%$ of strains with class 1 integron, indicating the role of Tn21 transposon in dissemination of integrons within the samples studied. The study gives baseline information on the resistance problem and its genetic background in contemporary poultry Enterobacteriaceae in Greece, and suggest the need for the introduction of surveillance programs to monitor antimicrobial resistance that can be potentially transmitted to humans. poultry

Key words: Enterobacteriaceae, integrons, multiresistance,

\section{INTRODUCTION}

Antibiotic usage is considered the most important factor that promotes the emergence, selection and dissemination of antibiotic-resistant bacteria in both veterinary and human medicine (Miles et al., 2006). The acquired resistance occurs not only in pathogenic bacteria, but also in the endogenous microflora of exposed animals and humans (Miles et al., 2006). Resistant animal pathogens 
may also be a threat to human health if these resistant bacteria enter the food supply or otherwise serve as reservoirs of resistance genes for human pathogens (Miles, et al., 2006; Bywater, et al., 2004). Because gram-negative bacilli of the family Enterobacteriaceae are common agents of food-borne diseases, great attention is focused on antibiotic resistance genes in this group of intestinal bacteria. Escherichia coli is a common inhabitant of the gastrointestinal tract of most animals, and in poultry it is known as a cause of extra-intestinal infections such as respiratory tract infections, septicemia and soft tissue infections (Maurer et al., 1998). Diseases of poultry caused by Escherichia coli result in significant economic losses every year (Maurer et al., 1998).

The major agents of gene transfer in the Enterobacteriaceae include the conjugative plasmids in which antibiotic resistance genes typically occur within genetic elements such as transposons and integrons. Integrons are genetic units containing elements for site-specific recombination, capture and mobilization of genes, including genes encoding resistance (Ploy et al., 2000). The defining gene of an integron is the intl gene encoding an integrase, a site-specific recombinase that inserts and removes small DNA cassettes, each encoding an antibiotic resistance gene (Ploy et al., 2000). More than 60 distinct resistance gene cassettes have been described (Kang et al., 2005). At least six classes of integrons, determined according to their intl gene, are known to have a role in the dissemination of antibiotic-resistance genes (Ploy MC et al., 2000). Class 1 and class 2 are the most frequently found in members of the family Enterobacteriaceae from both clinical isolates and normal flora of food animals, as well as in human clinical specimens (Goldstein et al., 2001). These classes are often located within transposable elements, Tn21 and Tn7 respectively (Goldstein et al., 2001; de la Cruz and Grinsted, 1982; Hall and Collis, 1995).

The purpose of this study was to investigate antimicrobial susceptibility among Enterobacteriaceae isolated from healthy and sick broiler chickens, and to investigate the association of reduced susceptibility to antimicrobial agents with the presence of integrons. The study was conducted in the region of Attiki, Greece, and included poultry husbandries belonging to few poultry enterprises that provide the broad market of Athens with fresh and frozen chickens.

\section{MATERIALS AND METHODS}

Bacterial strains and antimicrobial susceptibility testing

Forty-seven Enterobacteriaceae isolates were recovered from healthy (29) and sick (18) broiler chickens grown on 13 commercial broiler poultry farms in Greece over a three-month period (December 2005 through February 2006). The farms are situated in neighbouring regions belonging to three Prefectures, namely Evia, Viotia and Attiki. Feeding with addition of anticoccidioides is in use on all farms, and together with water supply, animal health and husbandry conditions are under control of the Central Veterinary Service of Chalkis (CVSC). Isolates were obtained from a variety of specimens including stool, liver, lower intestine, and gastrointestinal fluid. Specimens were taken either in cage or slaughterhouse from healthy chicken or after diseased chickens were sacrificed. All the isolates, 
belonging to the family Enterobacteriaceae, were identified to the species level by a commercial biochemical identification kit API 20E (bioMérieux, France). Antimicrobial sensitivity profiles of the isolates were established by the disk diffusion method in accordance with the recommendations given by the Clinical and Laboratory Standards Institute (CLSI) (Clinical and Laboratory Standards Institute, 2006). The isolates were tested for susceptibility to 18 antibiotics listed in Table 1. Escherichia coli ATCC 25992 was used as the control strain. All strains displaying intermediate susceptibility were considered to be resistant.

Typing with random amplification of polymorphic DNA (RAPD)

RAPD by polymerase chain reaction (PCR) was used as a rapid screening method to identify genetic differences among Escherichia coli isolates and to exclude potential repeated isolates as previously described (Maurer et al., 1998). Samples were distinguished by considering data from one PCR with the primer AP1290, 5'-CTGGATGCGA-3'. For each PCR, $5 \mu \mathrm{L}$ DNA was added to a reaction mix containing 10 pmol of primer, $0.2 \mathrm{mM}$ of each dNTP, $50 \mathrm{mM} \mathrm{KCl}, 10 \mathrm{mM}$ Tris$\mathrm{HCl}, \mathrm{pH} 9.0,0.1 \%(\mathrm{v} / \mathrm{v})$ Triton X-100, $1.5 \mathrm{mM} \mathrm{MgCl}_{2}, 0.2 \mathrm{mM}$ of each dNTP, and $1 \mathrm{U}$ Taq polymerase, made up to a total volume of $50 \mu \mathrm{L}$. Target sequences were amplified by PCR consisting of a 4 min denaturation step at $94^{\circ} \mathrm{C}$, followed by an initial amplification of 4 cycles of $1 \mathrm{~min}$ at $94^{\circ} \mathrm{C}, 1 \mathrm{~min}$ at $26^{\circ} \mathrm{C}$ and $1 \mathrm{~min}$ at $72^{\circ} \mathrm{C}$. A second round of amplification, consisting of 40 cycles of $45 \mathrm{~s}$ at $94^{\circ} \mathrm{C}, 45 \mathrm{~s}$ at $40^{\circ} \mathrm{C}$, and 2 min at $72^{\circ} \mathrm{C}$, was used.

\section{Bacterial DNA extraction and PCR amplification of integrase genes}

Bacterial DNA was extracted by the Qiagen mini prep kit (Qiagen, Germany). Integrons were detected using PCR with degenerate primers designed to hybridize to conserved regions of integron-encoded integrase genes int 1 , int/2 and int/3 as previously described (White et al. 2001). The class of the integron was determined by analysing integrase PCR products by restriction fragment length polymorphism (RFLP) following digestion using Rsal restriction enzyme as previously described (White et al., 2001). Previously described Escherichia coli strains with and without int/1 and int/2 were used as the positive and negative control strains.

Amplification and sequencing of gene cassette regions

Primers used to amplify class 1 integron cassette regions were: IL1 (5'GGCATCCAAGCAGCAAG-3') and IL2 (5'-AAGCAGACTTGACCTGA-3') as described previously (Levesque $C$, Roy $P H, 1993$ ). Class 2 integron cassette regions were amplified using hep74 (5'-CGGGATCCCGGACGGCATGC ACGATTTGTA-3') and hep51 (5'-GATGCCATCGCAAGTACGAG-3') as described previously (White et al., 2001). PCR amplifications were carried out in $50 \mu \mathrm{L}$ reaction mixtures containing $3 \mu \mathrm{L}$ of purified DNA, $10 \mathrm{pmol}$ of each oligonucleotide primer, $50 \mathrm{mM} \mathrm{KCl}, 10 \mathrm{mM}$ Tris- $\mathrm{HCl}, \mathrm{pH}$ 9.0, 0.1\% (v/v) Triton X$100,1.5 \mathrm{mM} \mathrm{MgCl}_{2}, 0.2 \mathrm{mM}$ of each dNTP, and $1 \cup$ Taq polymerase. All PCR reactions were performed for 35 cycles, each cycle consisted of $94^{\circ} \mathrm{C}$ for $1 \mathrm{~min}$, $55^{\circ} \mathrm{C}$ for $1 \mathrm{~min}$ and extension at $72^{\circ} \mathrm{C}$ for $1 \mathrm{~min}$ for amplification of the integrase 
genes, or $4 \mathrm{~min}$ for amplification of the cassette regions. Sequencing of the cassettes was performed at Lark Technologies, Essex, United Kingdom, after extracting, purifying and cloning of the amplicons using the Qiagen Cloning kit (Qiagen, Germany).

\section{Amplification and sequencing of merA gene}

Detection of mercuric reductase gene merA, as a marker for the presence of transposon Tn21, was performed by PCR amplification using the protocol previously described by Bass et al. (1999). Sequencing of the amplicon was performed after extracting, purifying and cloning of the amplicon using the Qiagen Cloning kit (Qiagen, Germany). Previously described Escherichia coli strains with and without merA gene were used as the positive and negative control strains.

Statistical methods

The significance of association of the presence of integrons and susceptibility to different antimicrobials was analyzed by using $\chi^{2}$ test.

\section{RESULTS}

\section{Characterisation of the isolates}

Out of 47 isolates of enteric bacteria recovered from the examined chicken samples, 43 were identified as Escherichia coli, one as Salmonella Typhimurium, one as Enterobacter sakazakii, and two as Proteus mirabilis. Based on RAPD patterns, $26 E$. coli analyzed strains appear to be genetically diverse, and fell into three major RAPD types and several unique types.

\section{Incidence of integrons, Tn21 and resistance patterns}

All of the isolates were screened for the presence of integrase genes int/1, int/2, and int/3, resulting in $491 \mathrm{bp}$ amplicons. Thirty-two strains were intl-PCR positive, indicating the prevalence of integron-containing isolates in the collection examined of $68.1 \%$. Int/1 amplicon does not contain an Rsal restriction site and remains intact after digestion. Int/2 amplicon contains one restriction site producing two restriction fragments of 334 and $157 \mathrm{bp}$, whereas int/3 contains two restriction sites producing three fragments of 290, 104 and $97 \mathrm{bp}$ (White et al., 2001). Amplification and Rsal digestion analyses revealed that 20 (42.5\%) strains carried a class 1 integron, five strains (10.6\%) carried a class 2 integron, and seven strains $(14.9 \%)$ had both class 1 and 2 integrons. No class 3 integronpositive isolates were detected. In total, 27 class 1 integrons and 12 class 2 integrons were identified in 32 of the 47 isolates.

The amplification of the merA gene, which is considered a marker for the presence of transposon Tn21, resulted in a 1230 bp fragment. Since non-specific PCR amplification products have been detected by agarose gel electrophoresis, sequencing was performed to confirm the presence of the mercury reductase $A$ gene. Out of 20 strains carrying class 1 integron and seven carrying both classes 1 and 2, nine and three strains were positive for merA respectively. In total, 44.4\% were positive for merA. 
Acta Veterinaria (Beograd), Vol. 61, No. 5-6, 575-584, 2011.

Dakić I et al.: Multidrug resistance and integrons in

Escherichia coli isolated from chicken in Greece

Out of 47 isolates, 39 (82.9\%) exhibited multidrug resistance, i.e. resistance to three or more antimicrobial agents with different mechanism of action. Most $E$. coli isolates recovered from healthy as well as from sick chicken were resistant to multiple classes of antimicrobials. Regardless of integron carriage high rates of resistance were found for the following antibiotics: ampicillin, cotrimoxazole and trimethoprim $(74.5 \%, 35$ strains), sulfamethoxazole $(53.2 \%, 25$ strains), tetracycline (46.8\%; 22 strains), nalidixic acid (38.3\%; 18 strains), and streptomycin $(29.8 \%, 14$ strains).

Table 1. Association between antibiotic resistance and integrons in 47 isolates of Enterobacteriaceae

\begin{tabular}{|l|c|c|c|c|}
\hline Antibiotic & $\begin{array}{l}\text { \% Resistance of 32 } \\
\text { int-positive isolates } \\
\text { (no. of resistant } \\
\text { isolates) }\end{array}$ & $\begin{array}{l}\text { Association } \\
\text { with } \\
\text { integron* }\end{array}$ & $\begin{array}{l}\text { \% Resistance of } \\
\text { 15 int-negative } \\
\text { isolates (no. of } \\
\text { resistant isolates) }\end{array}$ & $\begin{array}{l}\text { \% Resistance } \\
\text { of total (no. } \\
\text { of resistant } \\
\text { isolates) }\end{array}$ \\
\hline \hline ampicillin & $75 \%(24)$ & 0.832 & $73.3 \%(11)$ & $74.5 \%(35)$ \\
\hline $\begin{array}{l}\text { amoxicillin- } \\
\text { clavulanic acid }\end{array}$ & $12.5 \%(4)$ & 0.950 & $6.7 \%(1)$ & $10.6 \%(5)$ \\
\hline piperacillin & $6.2 \%(2)$ & 0.825 & $(0)$ & $4.2 \%(2)$ \\
\hline aztreonam & $3.1 \%(1)$ & 0.499 & $13.3 \%(2)$ & $6.4 \%(3)$ \\
\hline cefoxitin & $12.5 \%(4)$ & 0.950 & $6.7 \%(1)$ & $10.6 \%(5)$ \\
\hline cefotaxime & $6.2 \%(2)$ & 0.609 & $6.7 \%(1)$ & $6.4 \%(3)$ \\
\hline streptomycin & $37.5 \%(12)$ & 0.17 & $13.3 \%(2)$ & $29.8 \%(14)$ \\
\hline gentamicin & $3.1 \%(1)$ & 0.668 & $(0)$ & $2.1 \%(1)$ \\
\hline tobramycin & $3.1 \%(1)$ & 0.668 & $(0)$ & $2.1 \%(1)$ \\
\hline kanamycin & $28.1 \%(9)$ & $0.059 * *$ & $(0)$ & $19.1 \%(9)$ \\
\hline cotrimoxazole & $87.5 \%(28)$ & 0.009 & $46.7 \%(7)$ & $74.5 \%(35)$ \\
\hline sulfamethoxazole & $62.5 \%(20)$ & 0.120 & $33.3 \%(5)$ & $53.2 \%(25)$ \\
\hline trimethoprim & $87.5 \%(28)$ & 0.009 & $46.7 \%(7)$ & $74.5 \%(35)$ \\
\hline chloramphenicol & $28.1 \%(9)$ & $0.059 * *$ & $(0)$ & $19.1 \%(9)$ \\
\hline ciprofloxacin & $12.5 \%(4)$ & 0.415 & $26.7 \%(4)$ & $17 \%(8)$ \\
\hline enrofloxacin & $3.1 \%(1)$ & 0.887 & $6.7 \%(1)$ & $4.2 \%(2)$ \\
\hline nalidixic acid & $43.7 \%(14)$ & 0.427 & $26.7 \%(4)$ & $38.3 \%(18)$ \\
\hline tetracycline & $59.3 \%(19)$ & 0.027 & $20 \%(3)$ & $46.8 \%(22)$ \\
\hline
\end{tabular}

*Significant values are in bold

**Kanamycin and chloramphenicol (0.059) are only slightly above 0.05 significance limit

The susceptibilities of integron-positive and integron-negative isolates, and the association between the presence of integrons and reduced susceptibility to antimicrobials are presented in Table 1. Out of 39 multiresistant isolates, 30 (76.9\%) were integron-positive, while nine (23\%) were integron-negative. The association between the presence of integrons and multidrug resistance was 
significant $p<0.05(p=0.013)$. Namely, among 15 integron-negative isolates, nine $(60 \%)$ were multidrug resistant while 30 out of 32 integron-positive strains $(93.7 \%)$ displayed multidrug resistance. In addition, resistance to tetracycline (59.3\%; 19 strains) and trimethoprim (87.5\%; 28 strains) was also significantly associated with the presence of integrons, $p=0.027$ and $p=0.009$ respectively. Resistance rates to kanamycin and chloramphenicol were slightly above the significance limit $(p=0.059)$ for the association with integrons.

\section{Characterization of cassette arrays}

Out of 27 class 1 integron-positive isolates, cassettes were identified in 21 integrons. The cassette regions of six remaining class 1 integrons could not be amplified by PCR, possibly due to the lack of a hybridization site. Class 1 integrons harboured different cassette arrays from $1000 \mathrm{bp}$ to $2700 \mathrm{bp}$ comprising of aadA1, aadA2, aadA5, dfrA1, dfrA12, dfrA17. The most common types of cassettes carried by class 1 integrons were those conferring resistance to streptomycin and spectinomycin. These cassettes represented $53.7 \%$ of all cassettes found and included aadA1 (39\% of cassettes), aadA2 (4.9\%), and aadA5 (4.9\%). dfr cassettes (dfrA1, $-A 12,-A 17)$ that confer resistance to trimethoprim represented $41.5 \%$ of cassettes detected. The most common combination was aadA1, dfrA1 (52.4\%; 11 strains) conferring resistance to both streptomycin and trimethoprim. Five strains (23.8\%) contained a single antibiotic resistance gene, aadA1 (streptomycin-spectinomycin resistance). An unusual cassette aacA4catB3-dfrA1 was revealed in two isolates, one carrying class 1 integron and one carrying both class 1 and 2 integrons, within a cassette of $2700 \mathrm{bp}$. Analyses of 12 class 2 integrons identified cassettes of $\sim 1700 \mathrm{bp}$ in five strains and $2000 \mathrm{bp}$ in four strains, but sequencing data are not available. The cassette regions of three class 2 integrons generated no amplicons probably due to rearrangement or absence of a primer hybridization site.

\section{DISCUSSION}

The present study investigated 47 isolates of Enterobacteriaceae from broiler chickens with respect to their antimicrobial resistance and the presence of integrons as a potential basis for this resistance.

The overall data, including the result obtained in our study, show that antibiotic resistance among avian Enterobacteriaceae isolates is common and is of great concern to the poultry industry (Kang et al. 2005; Bass et al., 1999; Yang et al., 2004; Singh et al., 2005). This has also been shown in our study since over $80 \%$ of strains tested exhibited multidrug resistance.

A number of studies investigated the occurrence of integrons in selected populations of avian isolates of gram-negative bacilli (Bywater et al., 2004; Bass L et al., 1999; Johnson et al. 2005; Saenz et al., 2004), and prevalence ranging from $16 \%$ to $63 \%$ were reported (Kang HY et al., 2005; Bass et al., 1999; Yang et al., 2004; Singh et al., 2005). As far as rates of different classes of integrons are concerned, class 1 integrons appear to be prevalent in nature (Goldstein et al., 2001). The clear predominance of class 1 integrons we found is consistent with 
the results of previous studies (Kang et al., 2005; Goldstein et al., 2001; Bass et al., 1999; Yang et al., 2004; Kang et al., 2005) which also showed the highest frequency of occurrence of this class in poultry isolates. The dissemination of class 1 integrons has been attributed to the spread of a large $(19.7 \mathrm{~kb})$ integroncontaining transposon Tn21 (Goldstein et al., 2001; Bass et al. 1999). In addition to drug resistance, Tn21 confers mercury resistance through its mercuric reductase gene, merA (Bass et al., 1999). We searched for the presence of this gene in all strains containing class 1 integron and looked into the possibility that integrons in our isolates are actually part of Tn21. The gene was detected in $44.4 \%$ of the strains carrying class 1 integron, which indicates that at least a part of class 1 integrons spread within our isolates is related to Tn21. One possible explanation for this finding is the presence of a truncated derivative or a Tn4, a Tn21 derivative which does not confer mercury resistance because Tn3 has inserted into and disrupted the mer locus of Tn21 (Bass et al., 1999). The low incidence of class 2 integrons in the present study was similar to the distribution of this class in previously examined veterinary (Goldstein et al., 2001) and human urinary isolates (Chang CY et al., 2000). The results do not provide the basis for conclusions regarding the distribution of integrons among different bacterial species, since there were only four isolates of species other than Escherichia coli.

Many studies have shown a correlation between the presence of integrons and multiple-antibiotic resistance phenotype in enteric bacteria, with the class 1 integrons being the most prevalent (Singh et al., 2005; Fluit and Schmitz, 2004; Martinez-Freijo et al., 1998; Leverstein van-Hall et al., 2003; Grape et al., 2005; Mathai et al., 2004). This has also been shown in our study. Nevertheless, although the association between multidrug resistance and the presence of integrons was significant, $60 \%$ of integron-negative strains were multidrug resistant. This result indicates that the presence of integrons represents only one among many factors influencing the development of multidrug resistance. Several other factors promoting the emergence, selection and dissemination of resistant enteric strains have also been identified such as antibiotic usage, incomplete therapy, use of nontherapeutic antimicrobial growth promotants as feed additives for poultry (Miles et al., 2006), inappropriate use of disinfectants in farm environments (Randall et al., 2005), and mutations in the mar (multiple-antibioticresistant) locus regulation (Saenz et al., 2004). On the farms included in the present study, antibiotics are administered not only to individual diseased chicken but at the same time to the flock prophylactically which is considered potentially infected. This acquired resistance occurs not only in pathogenic bacteria but also in the intestinal microbial flora of exposed animals that can be passed onto people via food or through direct contact with animals (Miles et al., 2006).

It has been proposed that integrons are significantly associated with resistance to the older antibiotics (White et al., 2001; Fluit, 2004; Mathai et al., 2004). This was in part confirmed by results of the present study as indicated by elevated levels of resistance in integron-positive strains towards antibiotics such as chloramphenicol, tetracycline, ampicillin or kanamycin (Table 1). A high percentage of isolates were also resistant to antifolates (cotrimoxazole, sulfamethoxazole and trimethoprim). In contrast, only two isolates have exhibited resistance to enrofloxacin, a fluoroquinolone antibiotic approved for poultry use. 
The most prevalent types of cassettes carried by class 1 integrons were those conferring resistance to streptomycin and spectinomycin, and/or trimethoprim. This finding is in agreement with the high prevalence of these genes found in Enterobacteriaceae, including those isolated from human clinical specimens (Kang HY et al. 2005; White et al., 2001; Bass L et al. 1999; Yang et al., 2004). These aminglycosides are seldom used therapeutically, yet aadA gene cassettes remain prevalent within integrons and could demonstrate a form of genetic memory if reexposed to these antibiotics (White et al., 2001). Persistence of a specific resistance gene also occurs in human populations after decades without exposure to that antibiotic (Nandi et al., 2004), and it has been proposed that the likely basis for this persistence is physical linkage of genes for resistance to an older antibiotic with genes for resistance to a currently used antibiotic (Nandi et al., 2004). On the other hand, the high prevalence of $d f r$ cassettes might be attributed to the usage of trimethoprim in human medicine or the related veterinary analogue ormetoprim (White et al., 2001). Resistance gene cassettes were similarly abundant in strains isolated from all the farms included in the study. This result is consistent with results of previous studies investigating the incidence of genes associated with integrons among avian enteric bacteria, showing that a high prevalence of integron-related genes is not limited to farms using antibiotic growth promotants (Nandi et al., 2004). It is noteworthy that sequencing of two 2700 bp class 1 integrons revealed an arrangement of gene cassettes aacA4catB3-dfrA1 that has recently been described as a novel rearrangement in the class 1 integron in a Pseudomonas aeruginosa respiratory isolate ( $\mathrm{Li} \mathrm{X}$ et al., 2006). The explanation for the acquisition of this cassette type by the two species of unrelated genera and ecological niche does not seem evident.

In conclusion, the present study showed relatively high prevalence of integrons in isolates of enteric bacteria obtained from broiler chickens on Greek farms, and their significant association with reduced susceptibility to a range of antibiotics. These results further confirm the potential of integrons to contribute to development of resistance in Enterobacteriaceae. Their potential for transfer of antimicrobial resistance from enteric zoonotic bacteria of food animals to the human population is a cause of concern. It is, therefore, essential to continuously monitor bacterial susceptibility to antimicrobials and to study temporal trends among isolates from healthy animals. It is desirable that such studies should be repeated in the future years.

\section{ACKNOWLEDGEMENTS}

This work was supported by the EU Commission regional fund (75\%) and the Greek Ministry of Education (25\%). The authors are grateful to Prof. S. Stepanovic, MD, PhD, Institute of Microbiology and Immunology, School of Medicine, Belgrade, Serbia, for providing a helpful sounding board for the findings.

Address for correspondence:

Dr Ekatherina Charvalos, MD

School of Health and Caring Professions

Technological Educational Institution of Athens

Ag. Spyridonos/Palliakridou

12210 Athens, Greece

E-mail: gasson@aegean.gr 


\section{REFERENCES}

1. Bass L, Liebert CA, Lee MD, Summers AD, White DG, Thayer SG et al., 1999, Incidence and characterization of integrons, genetic elements, mediating multiple-drug resistance in avian Escherichia coli, Antimicrob Agents Chemother, 43, 2925-9.

2. Bywater R, Deluyker H, Deroover E, de Jong A, Marion H, McConville $M$ et al., 2004, A European survey of antimicrobial susceptibility among zoonotic and commensal bacteria isolated from food-producing animals, $J$ Antimicrob Chemother, 54, 744-54.

3. Chang CY, Chang LL, Chang YH, Lee TM, Chang SF, 2000, Characterization of drug resistance gene cassettes associated with class 1 integrons in clinical isolates of Escherichia coli from Taiwan, ROC, J Med Microbiol, 49, 1097-102.

4. Clinical and Laboratory Standards Institute (CLSI), 2006, Performance Standards for Antimicrobial Susceptibility Testing: Sixteenth Informational Supplement. CLSI document M100-S16, CLSI, Wayne, PA, USA.

5. de la Cruz F, Grinsted J, 1982, Genetic and molecular characterization of Tn21, a multiple resistance transposon from R100.1, J Bacteriol, 151, 222-8.

6. Fluit AC, Schmitz FJ, 2004, Resistance integrons and super-integrons, Clin Microbiol Infect, 10, 27288.

7. Goldstein C, Lee MD, Sanchez S, Hudson C, Phillips B, Register B, et al., 2001, Incidence of class 1 and 2 integrases in clinical and commensal bacteria from livestock, companion animals, and exotics, Antimicrob Agents Chemother, 45, 723-6.

8. Grape M, Farra A, Kronvall G, Sundstrom L, 2005, Integrons and gene cassettes in clinical isolates of co-trimoxazole-resistant Gram-negative bacteria, Clin Microbiol Infect, 11, 185-92.

9. Hall RM, Collis CM, 1995, Mobile gene cassettes and integrons: capture and spread of genes by site specific recombination, Mol Microbiol, 15, 593-600.

10. Johnson JR, Kuskowski MA, Smith K, O'Bryan TT, Tatini S, 2005, Antimicrobial-resistant and extraintestinal pathogenic Escherichia coli in retail food, $J$ Infect Dis, 191, 1040-9.

11. Kang HY, Jeong YS, Oh JY, Tae SH, Choi CH, Moon DC, et al., 2005, Characterization of antimicrobial resistance and class 1 integrons found in Escherichia coli isolates from humans and animals in Korea, J Antimicrob Chemother, 55, 639-44.

12. Kang SG, Lee DY, Shin SJ, Ahn JM, Yoo HS, 2005, Changes in patterns of antimicrobial susceptibility and class 1 integron carriage among Escherichia coli isolates, $J$ Vet Sci, 6, 201-5.

13. Leverstein van-Hall MA, Blok HEM, Donders ART, Paauw A, Fluit AC, Verhoef J, 2003, Multidrug resistance among Enterobacteriaceae is strongly associated with the presence of integrons and is independent of species or isolate origin, $J$ Infect Dis, 187, 251-9.

14. Levesque C, Roy PH, 1993, PCR analysis of integrons, In: Persing DH, Smith TF, Tenover FC, White TJ, Ed, Diagnostic molecular microbiology: principles and applications, Washington DC: ASM Press, 590-94.

15. Li X, Shi L, Yang W, Li L, Yamasaki S, 2006, New array of aacA4-catB3-dfrA1 gene cassettes and a noncoding cassette from a class-1-integron-positive clinical strain of Pseudomonas aeruginosa, Antimicrob Agents Chemother, 50, 2278-9.

16. Martinez-Freijo P, Fluit AC, Schmitz FJ, Grek VSC, Verhoef J, Jones ME, 1998, Class 1 integrons in gram-negative isolates from different European hospitals and association with decreased susceptibility to multiple antibiotic compounds, J Antimicrob Chemother, 42, 689-96.

17. Mathai E, Grape M, Kronvall G, 2004, Integrons and multidrug resistance among Escherichia coli causing community-acquired urinary tract infection in southern India, APMIS, 112, 159-64.

18. Maurer JJ, Lee MD, Lobsinger C, Brown T, Maier M, Thayer SG, 1998, Molecular typing of avian Escherichia coli by random amplification of polymorphic DNA, Avian Dis, 42, 431-51.

19. Miles TD, McLaughlin W, Brown PD, 2006, Antimicrobial resistance of Escherichia coli isolates from broiler chickens and humans, BMC Vet Res, 2, 7.

20. Nandi S, Maurer JJ, Hofacre C, Summers AO, 2004, Gram-positive bacteria are a major reservoir of class 1 antibiotic resistance integrons in poultry litter, PNAS, 101, 7118-22. 
21. Ploy MC, Lambert T, Conty JP, Denis F, 2000, Integrons: an antibiotic resistance gene capture and expression system, Clin Chem Lab Med, 38, 483-7.

22. Randall LP, Clouting CS, Gradel KO, Clifton-Hadley FA, Davies RD, Woodward MJ, 2005, Farm disinfectants select for cyclohexane resistance, a marker of multiple antibiotic resistance, in Escherichia coli, J Appl Microbiol, 98, 556-63.

23. Saenz Y, Brinas L, Dominguez E, Ruiz J, Zarazaga M, Vila J, et al., 2004, Mechanisms of resistance in multiple-antibiotic-resistant Escherichia coli strains of human, animal and food origins, Antimicrob Agents Chemother, 48, 3996-4001.

24. Singh R, Schroeder CM, Meng J, White DG, McDermott PF, Wagner DD, et al., 2005, Identification of antimicrobial resistance and class 1 integrons in Shiga toxin-producing Escherichia coli recovered from humans and food animals, J Antimicrob Chemother, 56, 216-9.

25. White PA, Mclver CJ, Rawlinson WD, 2001, Integrons and gene cassettes in the Enterobacteriaceae, Antimicrob Agents Chemother, 45, 2658-61.

26. Yang H, Chen S, White DG, Zhao S, McDermott PF, Walker RD, et al., 2004, Characterization of multiple-antimicrobial-resistant Escherichia coli isolates from diseased chickens and swine in China, J Clin Microbiol, 42, 3483-9.

\title{
MULTIREZISTENCIJA I INTEGRONI KOD SOJEVA BAKTERIJE ESHERICHIA COLI IZOLOVANIH KOD BROJLERA U GRČKOJ
}

\author{
DAKIĆ IVANA, PETRIKKOS G, DIMITRIJEVIĆ V i CHARVALOS E
}

\section{SADRŽAJ}

Crevna mikroflora životinja koje se koriste u ishrani ljudi, uključujući i crevnu mikrofloru živine, predstavlja potencijalni rezervoar gena rezistencije na antibiotike za bakterije koje su humani patogeni. U toku ove studije je iz različitih uzoraka uzetih od 29 zdravih i 18 bolesnih brojlera izolovano ukupno 47 sojeva Enterobacteriaceae od kojih je čak 43 identifikovano kao Escherichia coli. Kod svih izolata ispitana je osetljivost na 18 antibiotika, prisustvo integrona, kao i moguća povezanost integrona i rezistencije na antibiotike. Preko $80 \%$ izolata $(82,9 \%)$ je bilo multirezistentno. Integroni su bili prisutni kod $68,1 \%$ izolata i to: integroni klase 1 kod $42,5 \%$, integroni klase 2 kod 10,6\%, a obe klase kod 14,9\% sojeva. Treba istaći da je kod dva izolata sa klasom 1 integrona ustanovljeno prisustvo kasete aacA4-catB3-dfrA1, koja je do sada opisivana samo kod vrste Pseudomonas aeruginosa. Statistička analiza pokazala je značajnu povezanost prisustva integrona i multirezistencije $(p<0,05)$. Gen merA, odgovoran za rezistenciju na živu, detektovan je kod 44,4\% izolata sa klasom 1 integrona, što ukazuje na ulogu Tn21 transpozona u diseminaciji integrona unutar ispitivane grupe izolata. Ova studija pružila je prvi uvid u problem rezistencije i genetičku osnovu rezistencije izolata enetrobakterija kod živine u Grčkoj. Dobijeni rezultati ukazuju na potrebu uvođenja programa kontinuiranog praćenja rezistencije ovih bakterija, s obzirom na postojanje mogućnosti za transfer njihovih gena rezistencije na humane patogene. 